\title{
The Effect of He-Ne laser Radiation and Temperature of Blood in Vitro on the Erythrocytes Sedimentation Rate Values in Healthy People
}

\author{
Ferial. Y. Nazal ferial-y@utq.edu.iq \\ University of Thi-Qar / College of Medicine / Dept. of Medical Physics .
}

\section{$\underline{\text { Abstract }}$}

\section{Background :}

The aim of this study is to research the in vitro effect of the He-Ne laser radiation and study the effect of environmental temperature on Erythrocyte Sedimentation Rate (ESR) in blood samples from healthy .

Objective : To show the effect of He-Ne laser and effect of environmental temperature on Erythrocyte Sedimentation Rate (ESR)

Subject \& Methods : He-Ne laser wave length of $632.8 \eta \mathrm{m}$ was used for irradiation with $0.5 \mathrm{~mm}$ diameter beam spot on blood samples, with power density $1 \mathrm{mw} / \mathrm{cm}^{2}$, The irradiation times were $(1 \mathrm{hr})$, The samples of blood were obtained 30 contributors and each sample was separated into three samples for irradiation and control .

\section{Results :}

The results showed that there were significant differences in the values of sedimentation rates for both class $(25-45){ }^{0} \mathrm{c}$ degree heat compared with the values of sedimentation $25^{\circ} \mathrm{c}$ degree heat temperature for irradiation and control .

It shows the effect of temperature factor on the red blood cells sedimentation rate in blood samples from healthy people and see the effect of the degree of laboratory heat due to lack of efficient heating and cooling devices in the summer and winter on the sedimentation rates of values to be taken into consideration with the results .

Conclusion :The change of temperature (high and low) has a great effect on the deposition and precipitation of red blood cells in health people and thus must be taken into consideration and this effect is also observed with the use of $\mathrm{He}-\mathrm{Ne}$ laser at a temperature of $25^{\circ} \mathrm{C}$.

Keywords : Helium neon laser, Erythrocytes Sedimentation Rate (ESR), Temperature. 


\section{$\underline{\text { Introduction }}$}

The erythrocyte sedimentation rate is one of the most important principles underlying the Greek medicine, where it was discovered by the scientists of physics Sweden since 1915 and adopted by the Greeks in ancient medicine. the principles of this test established since the fifth century BC and subsequently developed by the worlds Aristotle ${ }^{[1][2]}$.As the deposition rate for the diagnosis of inflammation associated with acute cases and cancers using ${ }^{[3]}$.It depends on lasers effect on objects wavelength, light intensity, etc $^{[4]}$, So laser irradiation causes the optical interaction with cells instead of thermal effect.

Laser irradiation in this red spectral area increases the proliferative activity of cells and promotes tissue repair ${ }^{[5]}$. Cause the use of high-energy, especially in the surgical lasers to the destruction of tissue ${ }^{[6]}$.There are Several methods for determination of the ESR, westergren method, wintrobes method, landu method ${ }^{[7]}$.

ESR based on the principle of deposition rate of $\mathrm{RBC}$ in the bottom of the test tube and separated from the yellow liquid (plasma)which will be in the top ${ }^{[8]}$.Physiological factors that have an impact on sedimentation friction force on the red cell and change the surface of cells ${ }^{[3]}$.the effect of the low level laser irradiation on blood is very serious ${ }^{[9]}$, laser generally used now a day is the lowlevel laser are He-Ne laser emitting light at a wavelength of 632.8 $\mathrm{nm}^{[10][11]}$. RBC, $\mathrm{Hb}$ and HCT were highly effected by He-Ne laser act due to the strong absorption of irradiation light by HGB, but without damaging

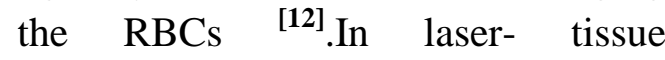
interaction, the incidence laser light on the certain tissue may be undergoing reflection, scattering, transmission or absorption. The effects of lasers on biological tissue are complex processes resulting from two interaction mechanisms: wavelength dependent interaction mechanism that includes: photothermal and photochemical interactions ${ }^{[13]}$. Interest in biostimulation effect of low intensity He-Ne laser, has increased in the last few years and the simulative effectiveness of electromagnetic radiation in the shape of low level laser light in biology and medicine ${ }^{[14]}$.

\section{Aim of the study}

To evaluate the effect of $\mathrm{He}-\mathrm{Ne}$ laser and effect of environmental temperature $(25,45)$ on Erythrocyte Sedimentation Rate (ESR)

\section{Methods and Materials}

The current study of case-control design included 30 healthy persons (male and female ) with age group (20-45 year). The patient are collected from Hussein Teaching hospital,Workplace in the laboratory of physiology and medical physicsthe time between April 2016 to July 2016. Blood samples collected in the anticoagulant clean pipes with textured tri-sodium citrate anti-coagulant of 30 healthy donors between the ages of sample 20-45year of male and female method was used and known Westergren way by the world Organization for laboratory measurements National Committee of 


\section{Email:utjmed@utq.edu.iq}

Clinical -Laboratory Standards ${ }^{[7]}$. pulling blood after mixing it quietly anticoagulant by Westergren absorbent and dry up to the mark $5 \mathrm{~mm}$ at the top of the tube with a note to avoid air bubbles in the blood column during the drag and fix pipes and put vertically on the stand. was used incubator seized every one of them to a certain temperature as selected temperatures are 25 degree that should be tested sedimentation rate of any considered the degree of control that it compares the rest of the results in the other thermal grades represent room temperature ranging from (20-25) ${ }^{0} \mathrm{c}$, while proving the temperature of the incubator second at a temperature of $45^{\circ}$ cand so as a thermal class that link to it degree laboratory daytime temperatures in the summer as the room temperature range in summer $\left(\begin{array}{ll}40 & -50\end{array}\right)^{0}$ cdegrees during the day inside the room . put the pipe carriers in each incubator and control the temperature of each incubator is $(25$ $, 45)^{0} \mathrm{c}$ and the samples were left in the incubator for one hour each degree heat was irradiated by laser radiation of is $\left(1.8 \mathrm{~J} / \mathrm{cm}^{3}\right)$ in the incubator $25^{\circ} \mathrm{c}$ degree and the second sample was
Web Site: https://imed.utq.edu.iq

kept without irradiation and served as control as a measure for comparison .That irradiation dose was reflected to be the laser energy per volume unit $\left(\mathrm{J} / \mathrm{cm}^{3}\right)$ The laser output power is 1 $\mathrm{mw}$, irradiation time is $60 \mathrm{~min}$ and the fluence is $1.8 \mathrm{~J} / \mathrm{cm}^{3}$. radiation doses were calculated using the equation:

$$
\begin{gathered}
f=\frac{p(w) * t}{v} \ldots . .[12] \\
\text { R.V. }=\frac{\Delta X}{X} \ldots \ldots[14] \\
\text { (where } \Delta X \text { is difference between before } \\
\text { and after irradiation ) } .
\end{gathered}
$$

The ESR ratio with laser radiation and red blood cells ESR(L) can be calculated by the following below equation :

$$
\operatorname{ESR}(L)=\frac{E S R \text { with laser radiation }}{\text { ESR without laser radiation control }}
$$




\section{$\underline{\text { Results }}$}

The results showed that there were significant differences in the values of sedimentation rates for both class $(25-45){ }^{0} \mathrm{c}$ degree heat compared with the values of sedimentation 25 ${ }^{0} \mathrm{c}$ degree heat temperature for irradiation and control .

It shows the effect of temperature factor on the red blood cells sedimentation rate in blood samples from healthy people and see the effect of the degree of laboratory heat due to lack of efficient heating and cooling devices in the summer and winter on the sedimentation rates of values to be taken into consideration with the results. As the temperature play a major and active role in the direct influence on the characteristics of the blood laboratory and thus giving a high error rate through its effect on the viscosity of plasma, where the low temperature leads to increased viscosity of plasma and thus reduce the red blood cells combines the rate and reduce sedimentation values and vice versa , and on this basis it was necessary to test the sedimentation rate at temperatures ranging from $(20-25)^{0} \mathrm{c}$ and the temperature rise most impact on sedimentation rates erythrocytes values it at a lower temperature . It may be concluded that laser radiation increases the rate of sedimentation of blood samples time, and table (1) shows the rates of sedimentation in the values of thermal grades (25-45) represents ( Means \pm Standard Deviation ).

Table1: Effect of Temperature on Erythrocyte Sedimentation Rate ( ESR )

\begin{tabular}{|c|c|c|c|}
\hline \multicolumn{2}{|c|}{ Variable } & \multirow{2}{*}{ Mean \pm Std. } & \multirow{2}{*}{ P-Value } \\
\cline { 1 - 3 } F/M & Temperature/ ESR & & \\
\hline $\mathbf{1 3 / 1 7}$ & $25 \mathrm{C}^{0}$ & $19.567 \pm 7.9250$ & $<0.01$ \\
\hline $\mathbf{1 3 / 1 7}$ & & & \\
\hline & $45 C^{0}$ & $25.900 \pm 8.5151$ & $<0.01$ \\
\hline
\end{tabular}


Table 2: The Effect of laser irradiation on erythrocyte sedimentation rate ESR after 60 min irradiation ( irradiance $1.8 \mathrm{~J} / \mathrm{cm}^{3}$ ) $\mathrm{P}<0.01 \quad \mathrm{~N}$ : Number of samples . The results of the effects of laser irradiation before and after irradiation are shown in the following table(2). A positive results in which the relative variation R.V. of a given between its value after irradiation and before irradiation .

\begin{tabular}{|c|c|c|}
\hline Temperature $\left(\mathbf{2 5} \mathbf{C}^{\mathbf{0}}\right)$ & Mean $\mathbf{+ S t d}$. & P-Value \\
\hline Control & $19.567 \pm 7.9250$ & $<0.01$ \\
\hline Irradiation & $20.0333 \pm 7.51772$ & $<0.01$ \\
\hline ESR $_{\mathbf{L}}$ & $1.0570 \pm 0.02493$ & $<0.01$ \\
\hline R.V. & $0.0547 \pm 0.02209$ & $<0.01$ \\
\hline
\end{tabular}

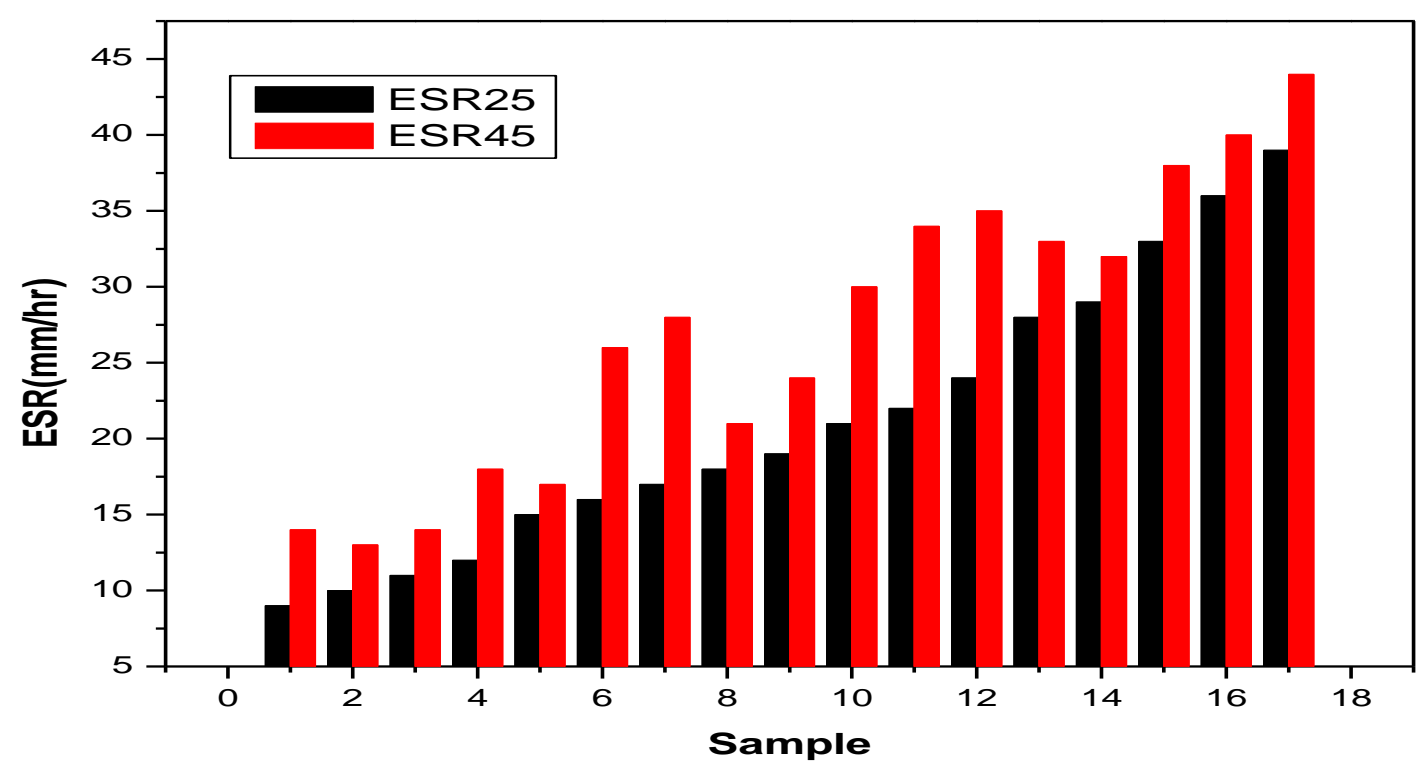

Figure (1) : Effect of Temperature $\left(25^{\circ} \mathrm{c}, 45^{\circ} \mathrm{c}\right)$ on Erythrocyte Sedimentation Rate ESR for Samples . 


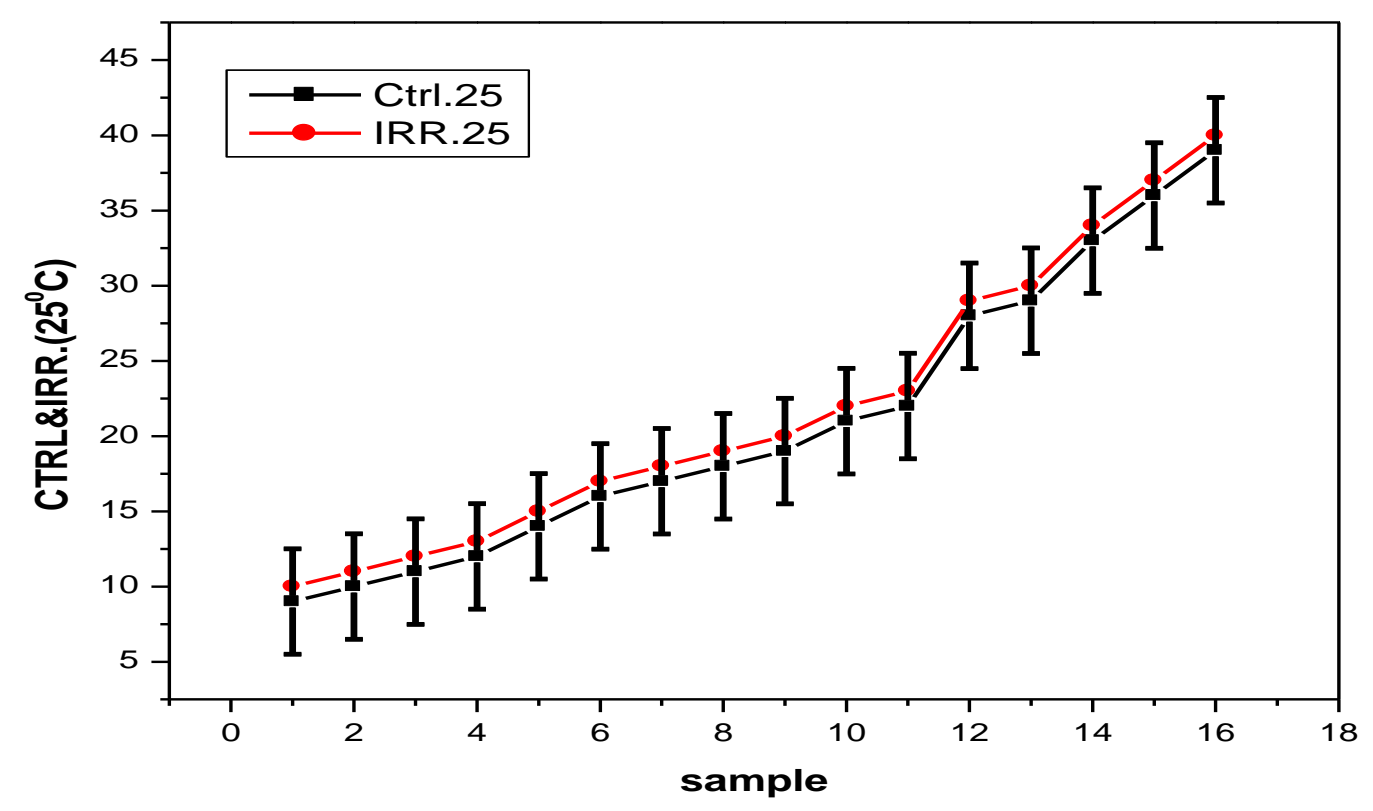

Figure (2) : The Effect of laser Irradiation on Erythrocyte Sedimentation Rate ESR after 60 minutes Irradiation .

Statistics analysis In this work, Use statistical analysis to determine the effect of temperature on the values of the deposition erythrocytes rates using a statistical program and to compare the severity of the impact of the change in temperature on the deposition rate, compared with a temperature control $25{ }^{\circ} \mathrm{c}$ by taking data deviation values of sedimentation rates in degrees $25-45^{\circ} \mathrm{c}$ a average data sedimentation rates in the values of temperature control $25^{\circ} \mathrm{c}$

the most crucial concern is the difference between the control and laser irradiation thus a paired t-test was used to evaluate the difference between the irradiated samples and nonirradiated control. All statistical analysis was performed with statistical package graph Pad software For those with significant difference, the percentage of relative variance (R.V.) was calculated to evaluate the extent of the relative change between irradiated and nonirradiated samples. 


\section{Thi-Qar Medical Journal (TQMJ): Vol.(12), No.(2), 2016 \\ Email:utjmed@utq.edu.iq \\ Web Site: https://imed.utq.edu.iq}

\section{$\underline{\text { Discussion }}$}

Sedimentation values affected by a number of factors, Some biological especially red blood cells while others are physically the circumstances surrounding some of the other mechanically to the manner of labor, materials and equipment used in this research were all factors affecting the values of sedimentation rates is installed so that the heat factor and laser source behind the wheel to test the deposition rate and through the use of blood samples, since the test was conducted just after the hour to combine in order to avoid the decomposition of the samples. Results showed values of the rates of sedimentation occurred within the normal rates when comparing with the natural values included in global measures mentioned by which range between (6-19) $\mathrm{mm} / \mathrm{h}$ at $25^{\circ} \mathrm{C}$. The decline in temperature and height from 25 to 45 to the direct impact on the values of sedimentation rates clearly, as the high temperature offset by a rise in the values of sedimentation rates, as it is the temperature factor one of the factors affecting the values of ESR and through the direct impact on the attractive forces of cell blood red, as increasingly attractive forces of erythrocytes with increasing temperature and vice versa.On the other hand result in a lower temperature to reduce the viscosity of plasma, which is one of the most important factors affecting the red blood cells collected and thus influence the Rouleaux phenomenon and reduce the ESR values.It has the current study was to demonstrate the effect of temperature factor on sedimentation rates of red blood cells Due to the advantage by some Iraqi provinces from the significant rise in temperatures in the summer offset relative decline in the winter and see the effect of the degree of laboratory temperature (not fitted with means of heating and cooling efficient) whether research of which belonging to hospitals or health centers different as well as interruptions continuing in power, as was the high temperature in the high moral values of sedimentation rates the values of $p$ $<0.01$ and thus conclude that the temperature of 25 degrees is the best thermal testing can hold the sedimentation rate .shows the effect of laser radiation on ESR for RBC levels increase with increasing the laser radiation. (In absence of plasma) the red blood cells became important chief factor of determining the erythrocyte sedimentation rate(ESR), to explain the increasing in ESR (L.) levels with increasing the dose laser radiation produce alteration in molecules by Intermolecular or intramolecular crosslinking is an effect caused by the creation of secondary bond between two molecules, (intermolecular crosslinking(or between two points of the same molecule, which were not linked before irradiation (intramolecular cross-linking) Cross-linking lead to increase the weight of molecule and decrease viscosity of the red blood cells these leads to the increase of the ESR ${ }^{[7]}$.

Conclusions: The change of temperature (high and low) has a great effect on the deposition and precipitation of red blood cells in health people and thus must be taken into 


\section{Email:utjmed@utq.edu.iq}

consideration and this effect is also observed with the use of $\mathrm{He}-\mathrm{Ne}$ laser at a temperature of $25^{\circ} \mathrm{C}$.

\section{$\underline{\text { Recommendations }}$}

1. The need for a test deposition rate of red blood cells at temperatures ranging from $(20-25){ }^{0} \mathrm{C}$.

2. equip laboratories (research centers or scientific) with conditioning and heating with high efficiency.

3. Study the impact of the type of material anticoagulant on the values of deposition rate and install the rest of the influencing factors.

\section{$\underline{\text { References }}$}

1- Rhoades, R.A. and Tanner, G.A: Medical physiology. 2nd ed. Elsevier Philadelphia, Pennsylvania ,2012, Pp.(739) .

2- Turgeon, M.L.(Ed.) : Clinical Hematology, theory and procedures. 1st ed., Little ,Brawn and Company, Boston, 1998, 326pp .

3- Ammal Esmaeel Ibrahim, Suhad Abdul Azeez Ibrahim, Dhuha Hashem Fadhel, and Amir Adnan Hussein , Sedimentation Levels of Red Blood Cells (ESR) and its Effect on Viscosity of Blood Cells (PVC) and Glucose in Elderly People , Journal of Al-Nahrain University, 2014, pp.912Vol.17 (2), June .

4- Kassak, P.; Sikurova, L.; Kvasnicka, P., and Bryszewska, M.: The response of $\mathrm{Na}+/ \mathrm{K}+-$ ATPase of human erythrocyte to green laser light treatment. Physiological research.2006, PP. 189-194Vol. 55.
Web Site: https://imed.utq.edu.iq

5- JenanH. Taha BSc, Fikher S. AL-AniMBChB, MSc, PhD ,Wijdan F. AL-Siaidy BSc, PhD , Protection Properties of He-Ne Laser (632.8 nm) Against UV-light $(253.7 \mathrm{~nm})$ On the Lymphocytes Blood Cells and Its DNA, J Fac Med Baghdad 2012Vol.54, No.3.

6- AmalYousif Mohsen Al-Yasiri MSc , Effect of $650 \mathrm{~nm}$ Diode Laser on the Cross-Bonding Formation of Human RBC Membrane , Iraqi J. Comm. Med., July, 2009, 22 (3) .

7- Ahmed A. Ibrahim: A new automated method for the determination of erythrocyte sedimentation rate (ESR ) , Journal of Kirkuk University Scientific Studies 2007, Vol.2,No.3.

8- WRHA Laboratory Medicine Program. "Guidelines for ordering erythrocyte sedimentation rate (ESR)". Effective Date 2004. [Clinical Guideline],from Diagnostic Services of Manitoba Inc. at Retrieved June 26, 2006

9- Samira M. Sallam , Abdelsattar M. Sallam , El-Sayed M. ElSayed , L. I. Abo Salem ,Mona M. Rizk , Enhancement of Human Blood Storage Period by Irradiation of Low Level He$\mathrm{Ne}$ Laser , Journal of Biophysical Chemistry, 2015, 6, 77-86.

10- Relevy, H., Koshkaryev, A., Manny, N., Yedgar, S. and Barshtein, G. Blood Banking-Induced Alteration of Red Blood Cell Flow Properties. Transfusion, 2008 , 48, 136-146.

11- Brill, A.G., Shenkman, B., Brill, G.E., Tamarin, I., Dardik, R., Kirichuk, V.F., et al. Blood Irradiation by He-Ne Laser Induces a Decrease in Platelet Responses to Physiological Agonists and an Increase in Platelet Cyclic GMP. Platelets, 2000 , 11, 87-93.

12- Yousry M Mostafa, Sherif N Amin, Samir Abd al wahaband Alsayed AM Elsherbini : Effects of Non-Coherent 
Thi-Qar Medical Journal (TQMJ): Vol.(12), No.(2), 2016

and Coherent Light on Complete Blood Picture and Osmotic Fragility of Human Blood, Mostafa et al., J Blood Disorders Transf 2013, 4-1.

13-Ayad G. Anwer : Stimulation of Phagocytic Activity of Human Polymorphonuclear Leukocytes in Vitro Using $10 \mathrm{~mW}$ He-Ne Laser, Iraqi J. Laser, Part B, 2005 ,Vol. 4, pp. 23-27.
14- Lewis, S.M.; Barbara, J.; Bain I.; Imelda B : Practical Hematology. 9th ed. Churchill Livingstone, 2001 pp.527531 . 


\section{تاثير اشعة ليزر الهيليوم - نيون ودرجة الحرارة على معدل ترسيب كريات الام الحمراء}

فريال يونس نزال

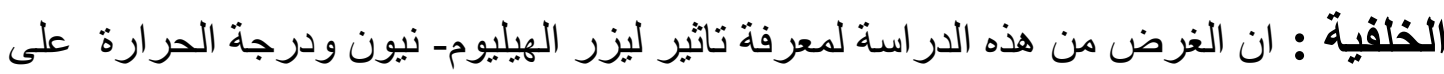

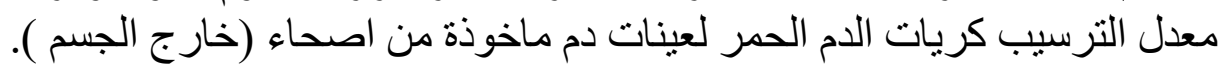

كريات الدم الحمر

الهدف : اظهار ناثير ليزر الهيليوم - نيون ودرجة حرارة البيئة على معدل نرسيب

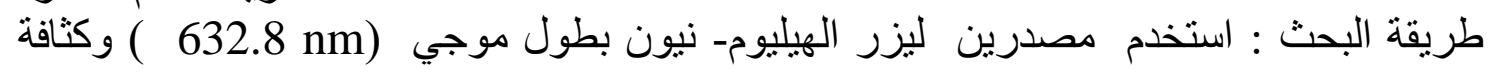

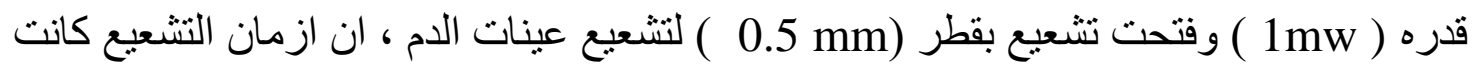

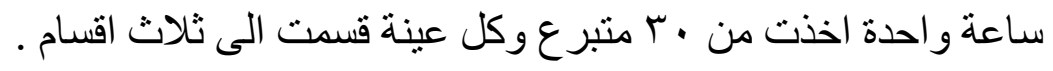

النتائج : اظهرت النتائج وجود فروق معنوية في قيم معدلات الترسيب عند المقارنة بدرجني

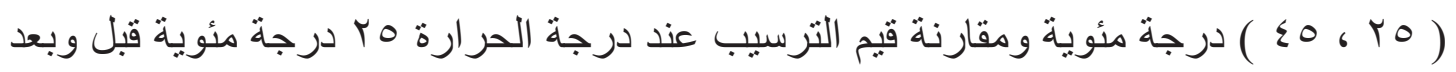

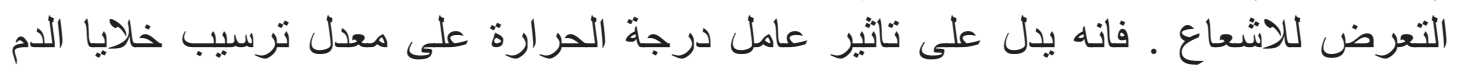

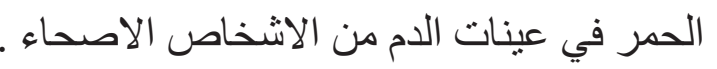

الاستنتاجات :يمكن الاستتناج ان التغير في درجة الحرارة ( الارتفاع و الانخفاض ) يؤثر على الإنى

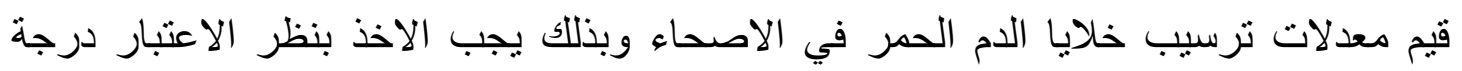

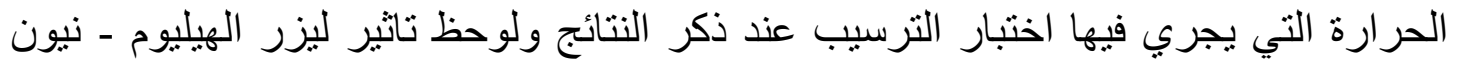
بدرجة حرارة O Y درجة مئوية . 